\title{
Development of science assessment instruments based on entrepreneur
}

\author{
Indah Sukmawati ${ }^{1}$ *, Sarjono Sarjono ${ }^{2}$ \\ ${ }^{1}$ Sekolah Menengah Pertama Negeri 3 Pemalang. Bojongbata, Pemalang, Jawa Tengah 52319, Indonesia \\ ${ }^{2}$ Madrasah Aliyah Negeri Pemalang. Jalan Tentara Pelajar No.12, Mulyoharjo, Pemalang, Jawa Tengah 52319, Indonesia \\ * Corresponding Author. Email: indahsukmawati354@gmail.com
}

\begin{tabular}{|c|c|}
\hline & ABSTRACT \\
\hline $\begin{array}{l}\text { Keywords: } \\
\text { Science, interest in } \\
\text { entrepreneurship, } \\
\text { politomous }\end{array}$ & $\begin{array}{l}\text { This study aims to produce (1) an instrument of assessment of learning outcomes for } \\
\text { entrepreneurship-based science and (2) a questionnaire of student entrepreneurial interest. This } \\
\text { study is a research and development (R\&D) with reference to the modified Borg \& Gall. The } \\
\text { research period was from August } 2019 \text { to November } 2019 \text { at SMP Negeri } 3 \text { Pemalang involving } \\
\text { a total of } 307 \text { students. The content validation index by experts with V'Aiken for the test } \\
\text { instrument for learning outcomes based on entrepreneurship and student questionnaire interest in } \\
\text { entrepreneurship are } 0.91 \text { and } 0.87 \text {, respectively. The results show that at the trial stage based on } \\
\text { the MNSQ mean INFIT of } 1.00 \text { criteria and the standard deviation of } 0.00 \text {, it is evident that both } \\
\text { the tests and questionnaires are both fit with the PCM } 1 \text { PL model. Based on the lowest and } \\
\text { highest thresholds of INFIT MNSQ, i.e.: } 0.77 \text { to } 1.30 \text {, the instrument of the science-based } \\
\text { learning entrepreneurship and questionnaire interest in student entrepreneurship produce } 16 \text { and } \\
8 \text { valid items with reliabilities of } 0.89 \text { and } 0.85 \text {, respectively. So it can be concluded that the } \\
\text { developed instrument has a high validity and reliability index, so it is ready to be used by } \\
\text { science teachers of SMP or MTs for assessment. }\end{array}$ \\
\hline
\end{tabular}

C2019 JSER. Yogyakarta State University

\section{INTRODUCTION}

The development of Entrepreneurship education is one of the programs of the Ministry of National Education which in essence is the development of an educational methodology that aims to build people who are creative, innovative, sportsmanlike, and entrepreneurial (Ministry of National Education, 2010). Entrepreneurship education is a life skill education. For students entrepreneurship education is a very important program that needs to be disseminated in the realm of formal education. Considering that not all students are able to continue their education because of costs or other reasons. Along with the current globalization and the development of science and technology as well as the era of the 4.0 Industrial Revolution, it is necessary to have a new breakthrough in carrying out science learning in class. Students need to be given high motivation and an advanced and responsive attitude to the surrounding environment in order to be able to follow the development and progress of Science and Technology. One of the effects of the development and progress of science and technology is the difficulty of getting decent jobs in accordance with the field of expertise. Moreover, many students of SMP or MTs who are unable to continue to a higher level for some reason. Meanwhile, graduates of SMP or os did not have enough provision to enter the field of work or entrepreneurship. Therefore, students of SMP or MTs need to be given an understanding of entrepreneurship as a provision to start or continue their activities properly when they graduate, especially those who are unable to continue their studies.

Students at the SMP or MTs level should be introduced to finance entrepreneurship. One of the proper introductions is through entrepreneurialbased learning, thereby fostering interest in entrepreneurship. According to Purnomo (2005, p. 122), students' interest in entrepreneurship can be increased through education. It is not enough for students to only master theories, but also be willing and able to apply them in social life. Students are not only able to apply the knowledge gained in school, but also able to solve various problems encountered in everyday life. This kind of education is oriented to the formation of entrepreneurial interests. Entrepreneurial education, especially at the SMP or MTs level can be applied to students through an integrated curriculum developed in schools. According to Usman and Raharjo (2012, p. 142) there are three competencies that must be possessed by a successful 
entrepreneur, i.e.: knowledge, skills, and the nature of entrepreneurship.

Students' entrepreneurial spirit can be developed by the school environment through entrepreneurial-based learning. Many students have the advantage of being a studentpreneur, meaning that a student is also an entrepreneur. A studentpreneur is a student who runs a business while still studying, which not only develops the student's business but also builds relationships with others from different disciplines (Torenberg, 2012).

Based on the above considerations, planning is needed to develop learning tools about education that can increase student motivation and student entrepreneurial interest. The availability of learning tools is one of the factors that can support the learning process and improve the quality of education. The learning model and learning tools are expected to improve student motivation and student entrepreneurial interest.

Entrepreneurship education can be applied into the curriculum by identifying school activities or subject matter that can be integrated with entrepreneurship education. This is in accordance with Mulyani (2010, pp. 58-65) which state that entrepreneurship education can be internalized through several ways, including integrated entrepreneurship education in subjects. Entrepreneurship education integrated into subjects can become a habit of entrepreneurial values in learning activities. This can foster student entrepreneurial interest.

The step of integrating entrepreneurship education into learning can be done when delivering material through learning methods and assessment systems. Of course, teachers must make preparations to make learning tools based on entrepreneurship, such as making syllabus, lesson plans, teaching materials, and assessment of learning outcomes based on entrepreneurship.

This study aims to (1) produce a set of entrepreneurial-based learning, (2) improve student learning outcomes, and (3) foster entrepreneurial interest in students. As for the formulation of the problem in this study are (1) how to produce entrepreneur-based learning tools? (2) How far is the increase of student learning outcomes? (3) How interested are the students in entrepreneurship?

\section{METHOD}

This study is a research and development ( $R$ $\&$ D), which aims to solve practical, contextual, and actual problems in SMP or MTs, namely the development of learning tools and assessment instruments based on entrepreneurship. This study uses two types of instruments, viz.: an instrument of assessment of entrepreneurial-based learning outcomes and questionnaire of students' interest in entrepreneurship. This R \& D research refers to the development model according to Borg \& Gall (1983, p. 775) with the following steps: (1) research and information collecting, (2) planning, (3) developing preliminary form of the product, (4) preliminary field testing, (5) main product revising, (6) main field testing, (7) operational product revising, (8) operational field testing, (9) final product revising, and (10) disseminating and implementing the product.

The choice of the R \& D model mentioned above is because the procedure is relatively more complete and detailed so that it is easy to follow and easy to modify. Broadly speaking, the development steps mentioned above can be simplified into three stages, namely: (1) the pre-development stage; (2) the trial phase; and (3) the implementation phase.

The pre-development stage includes determining the purpose of the test, determining the competency being tested, determining the material being tested, compiling the test lattice, writing items or statements based on the question indicators, assembling the test, preparing guideline for scoring (assessment rubric), content validating tests by several experts; and improving the items and assembling the test.

This study uses partial credit model (PCM) 1PL for testing the fit of instrument items. The trial phase includes determining the test subjects of junior high school students on a limited scale, determining the trial time, conducting the trials, analyzing the trial data, revising items that do not fit, assembling the test again, and implementing the test. This research has not yet reached the implementation stage due to limited time, energy, and cost.

The research was conducted from August 2019 to November 2019. The research site was SMP Negeri 3 Pemalang Indonesia. The subjects of this study were all Grade IX students of SMP Negeri 3 Pemalang, Indonesia.

\section{Procedure}

The development steps of Borg \& Gall (1983) are explained as follows:

\section{Need Analysis}

The need analysis is done by reviewing the curriculum and syllabus used in SMP Negeri 3 Pemalang. Then we identify the material students used in learning as a basis for making the instruments.

\section{Develop the Initial Products}

The initial stage of the initial product development is the making of a grid that refers to the syllabus. Then determining the format of the test, which is an instrument for evaluating cognitive 
aspects in the form of politomus scores which are categorized in three categories, i.e.: 1, 2, and 3.

Expert validation and revision

Expert validation is carried out by seven senior teachers in their fields.

\section{Testing}

The trial is carried out on 307 students of Grade IX of SMP N 3 Pemalang.

\section{Analysis technique}

The data analysis technique of the trial results includes several aspects, namely: (a) Goodness of fit for PCM; (b) item validity; (c) instrument reliability; and (d) information and SEM functions.

\section{Goodness of fit for PCM}

Fit testing on the overall test is based on mean values and standard deviations from INFIT MNSQ. If the MNSQ INFIT average is close to 1.00 and the standard deviation is close to 0.00 , then the overall item is fit in the PCM model. This is done with the help of the QUEST program.

Item validity

According to the rules of Adams and Khoo (1996, p. 30) an item is fit to the model if the value of INFIT MNSQ is in the range of 0.77 to 1.30 .

Instrument reliability

According to Mardapi (2012) an instrument is classified as good if it has a reliability coefficient or a reliability index equal to or greater than 0.70 . The instrument reliability estimation can be seen based on the output of the QUEST program analysis, both the reliability for items and the reliability for the tests.

Information and SEM functions

Estimation of information and SEM functions is done with the help of the PARSCALE program. Based on the information and SEM functions, the test looks suitable with certain ability tests high, medium, or low.

\section{RESULT AND DISCUSSION}

\section{Results of Instrument (Test) Assessment of Learning Based on Entrepreneurship Science}

Based on the Figure 1, it can be seen that from the 17 items available, after analysis with Quest, there are 16 valid items and 1 invalid item, namely item number 12 which is outside the line.

Table 1. Estimated Test Points

\begin{tabular}{llc}
\hline No. & Description & Estimation \\
\hline 1. & Reliability & 0.89 \\
2. & INFIT MNSQ & $0.88-1.21$ \\
3. & Average INFIT MNSQ & $1.01 \pm 0.03$ \\
\hline
\end{tabular}

Based on Table 1, it can be seen that the result of the reliability test is 0.89 . The item validity is shown in the MNSQ INFIT values in the range of 0.88 to 1.21 (which is in the range of 0.77 to 1.30 ). The mean value and standard deviation of INFIT MNSQ is $1.01 \pm 0.03$, thus it can be said that all items are fit according to the PCM model.

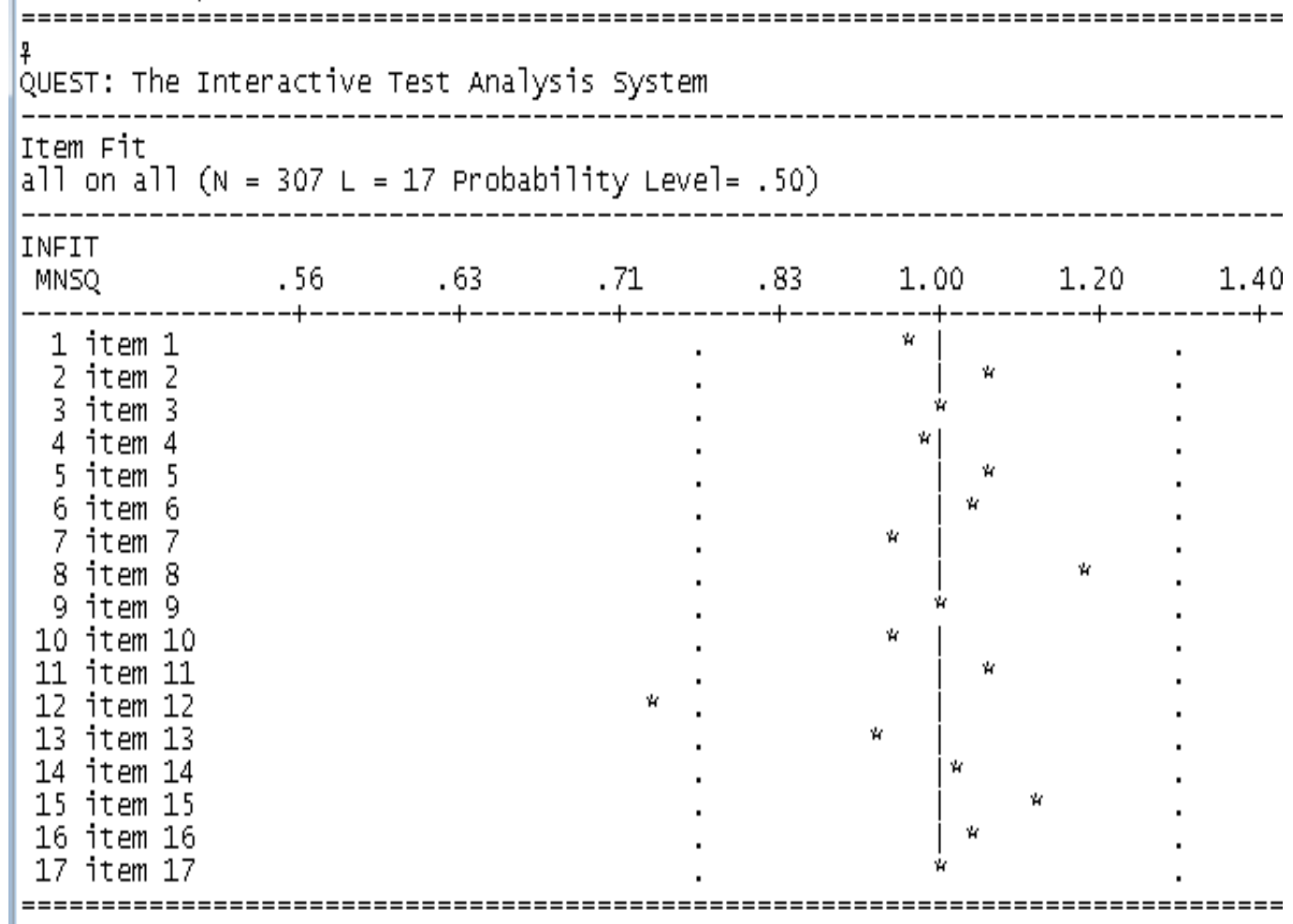

Figure 1. MNSQ Infit Test Diagram 


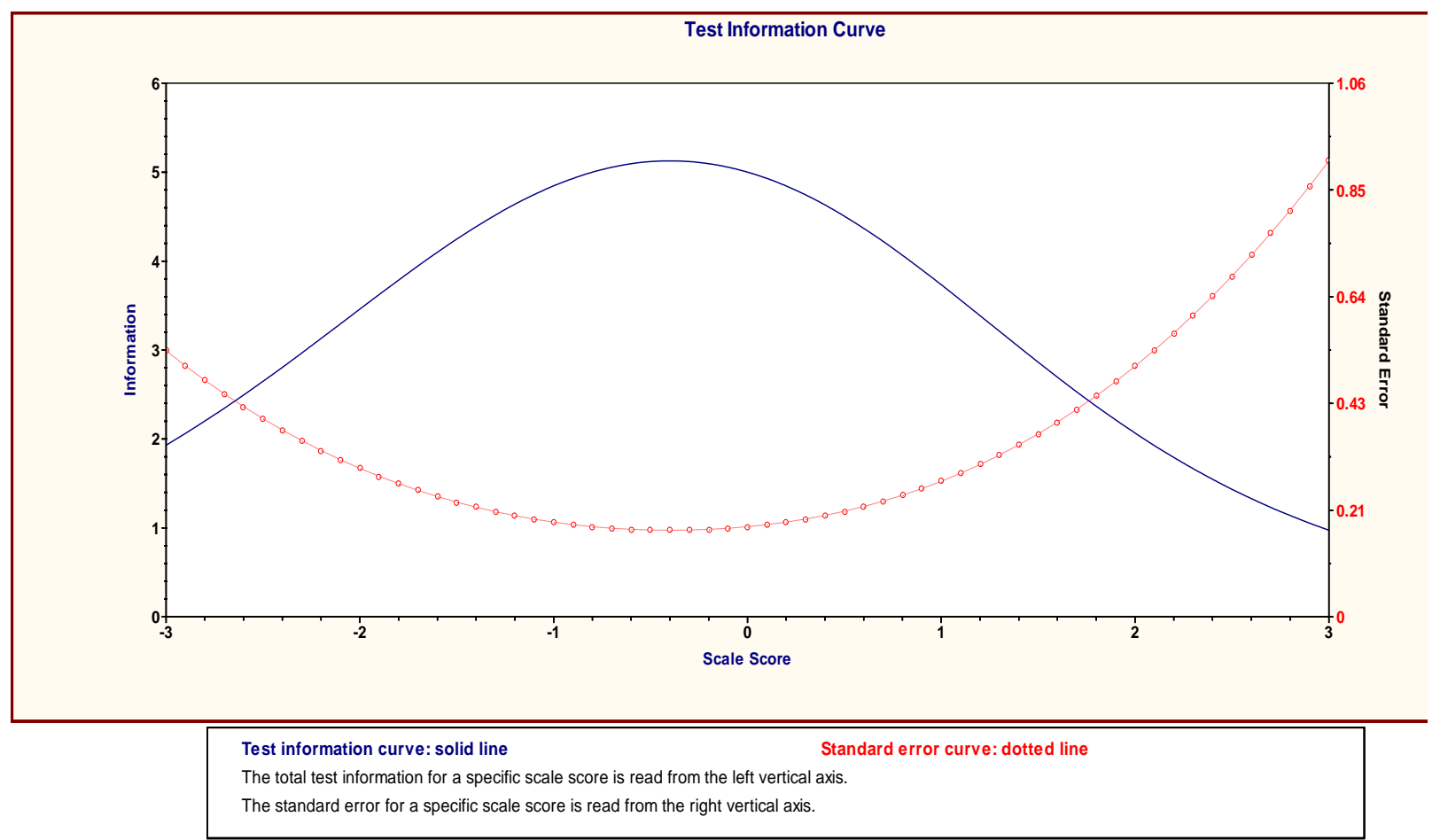

Figure 2. Information Function and SEM Test for Assessment of Entrepreneurship Based Science Learning Outcomes.

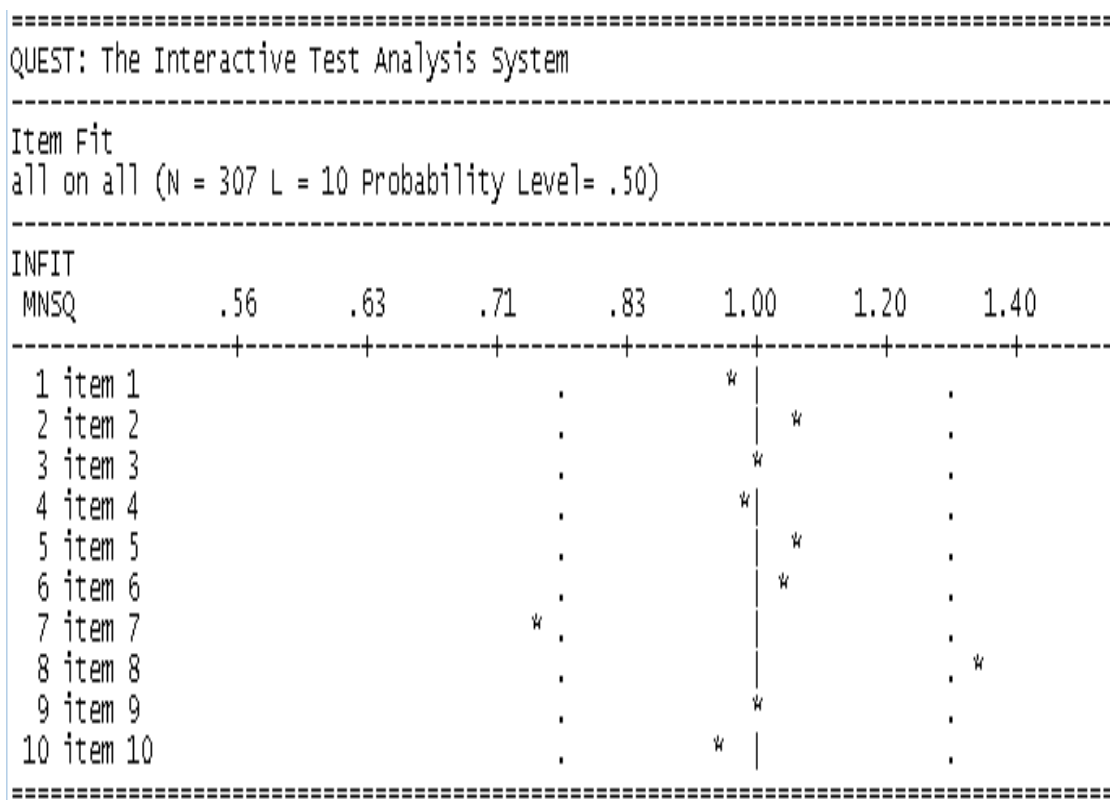

Figure 3. MNSQ Questionnaire INFIT Diagram

Based on Figure 2 of the graph of information and SEM functions it can be seen that the higher order thinking skills instrument is suitable for capable students between -1.40 to 1.80 . This wide range of abilities is very appropriate to be applied to SMP or MTs given the input of students having diverse backgrounds.

\section{Instrument (Questionnaire) Student Entrepreneurial Interest}

Based on Figure 3, it can be seen that out of 10 items, after analyzing the items with Quest, there are 8 valid items and 2 invalid items, namely item number 7 and number 8 which are outside the line.

Table 2. Estimated Item Questionnaire

\begin{tabular}{llc}
\hline No. & Description & Estimation \\
\hline 1. & Reliability & 0.85 \\
2. & INFIT MNSQ & $0.97-1.14$ \\
3. & Average INFIT MNSQ & $1.02 \pm 0.05$ \\
\hline
\end{tabular}

Based on Table 2, it can be seen that the result of the reliability test is 0.85 . The item validity is shown in the MNSQ INFIT value in the range of 0.97 to 1.14 (which is in the range of 0.77 to 1.30 ), which indicates that the item is valid. The mean 
value and standard deviation of the INFI MNSQ are $1.02 \pm 0.05$. Thus it can be said that all items are fit according to the PCM model.

\section{CONCLUSION}

Based on the results and discussion above, it can be concluded that the instrument for evaluating the learning outcomes of entrepreneurship-based science in the form of tests consists of 16 valid and reliable items. The items have fulfilled content validity with expert judgment and have obtained empirical evidence of fit on PCM based on three categories of politomus data. Moreover, the instrument of student entrepreneurial interest in the form of a questionnaire consists of 8 valid and reliable items. The items have fulfilled content validity with expert judgment and have obtained empirical evidence of fit on PCM based on three categories of politomus data. Hence, the test instruments and questionnaires are ready to use by science teachers.

The results of this study are of great benefit to researchers in the field of evaluating learning outcomes and increasing student entrepreneurial interest. This study can be used as a guideline or modelin developing entrepreneurship-based science assessment instruments. Moreover, the results of this study can be used as a reference or guide for science teachers in junior high schools in conducting science learning in their schools.

This study uses a sample of Grade IX students at the junior high school level. Therefore it is recommended for researchers to use a broader sample involving students of senior high school level. Further research is needed to find out the difficulties experienced by students and teachers while using the developed instruments. Moreover, it is recommended that SMP or MTs teachers use the instruments that have been developed, so that teachers need to train students before the instruments are used for assessment. The teacher also needs to adjust the learning method with the instruments developed, so students are used to the instrument. SMP or MTs teachers need to provide students with an understanding of the importance of entrepreneurial-based assessments that have received less attention. It is also helpful to hold a workshop related to the procedure of developing entrepreneurial-based instruments for SMP or MTs teachers, especially in the natural science subjects, so that teachers understand in carrying out learning and assessment related to entrepreneurship. There should also be a research and development institute in every district that functions to provide enlightenment or consultancy for SMP or MTs teachers who want to develop instruments related to entrepreneurship. Finally, training should be held concerning programs used to analyze research data, such as EXCEL, QUEST, PARSCALE, and LISREL.

\section{REFERENCES}

Adams, R. J., \& Khoo, S. T. (1993). Quest: The interactive test analysis system. Victoria: The Australian Council for Educational Research

Borg, R. W. \& Gall, D.M. (1983). Educational Research. New York, Logaman, inc.

Chen, W. Y., Weng, C. S. \& Hsu, H.Y. (2010). A study of the entrepreneurship of Taiwanese youth by the Chinese Entrepreneur Aptitude Scale. Journal of Technology Management in China, 5(1), 26 - 39.

Depdiknas. (2010). Panduan Pendidikan Karakter di SMP. Balitbang Depdiknas. Jakarta.

Lestari, R. B., \& Wijaya, T. (2012). Pengaruh pendidikan kewirausahaan terhadap minat berwirausaha mahasiswa di STIE MDP, STMIK MDP, dan STIE MUSI. In Forum Bisnis Dan Kewirausahaan Jurnal Ilmiah STIE MDP (Vol. 1, No. 2, pp. 112-119). STIE MDP.

Mardapi, D. (2005). Pengembangan instrumen penelitian pendidikan. Yogyakarta: PPs. Universitas Negeri Yogyakarta.

Mulyani, E. (2010). Pengembangan pendidikan kewirausahaan. Jakarta: Kemendiknas.

Purnomo, B. H. (2005). Membangun semangat kewirausahaan. Yogyakarta: Laksbang Pressindo.

Purwana, D., \& Wibowo, A. (2017). Pendidikan Kewirausahaan di Perguruan Tinggi. Yogyakarta: Pustaka pelajar.

Torenberg, E. (2012). Find your inner entrepreneur. The Michigan Daily, 12-9.

Usman, H., \& Raharjo, N. E. (2012). Model Pendidikan Karakter Kewirausahaan di Sekolah Menengah Kejuruan. Jurnal Pendidikan Teknologi dan Kejuruan, 21(2). 